\title{
PREDICTIVE IMPORTANCE OF TUMOR BUDDING, LYMPHOVASCULAR AND PERINEURAL INVASION IN COLORECTAL CARCINOMA
}

\author{
Tijana Denčić1,5, Maja Jovičić-Milentijević1,5, Aleksandar Petrović2 , Goran Radenković2, \\ Marko Jović2 ${ }^{2}$ Sonja Šalinger-Martinovićs, ${ }^{3,6}$, Simona Stojanović ${ }^{4}$
}

\begin{abstract}
Colorectal cancers comprise a heterogeneous group of malignant intestinal tumors that have various mechanisms of onset, based on different combinations of genetic and epigenetic alterations. Many authors suggest that the TNM staging most accurately determines the prognosis of each case of colorectal cancer, however other parameters that indicate the aggressive behavior of the tumor are required as well. Such parameters involve perineural invasion, lymphovascular invasion, and tumor budding. The aim of this paper was to examine association between perineural invasion, lymphovascular invasion, and tumor budding with the tumor stage in colorectal cancers. The study included histopathology cases of 142 large bowel cancers removed at the Surgical Clinic in Niš during the period of one year (2016). The tumor stages were determined based on the TNM classification recommended by AJCC. Perineural invasion, lymphovascular invasion, and tumor budding were relatively common finding: 20.4, $40.1,44.4$ percent of examined cases, respectively. Univariate logistic regression analysis revealed a statistically significant correlation between high grade tumor budding, lymphovascular and perineural invasion and the advanced stage of tumor disease. The evaluation method, according to the International Tumor Budding Consensus Conference (ITBCC), should be used to evaluate/define biological aggressiveness of a tumor, and may represent the basis of a routinely used staging system in patients with colorectal cancer.
\end{abstract}

Acta Medica Medianae 2020;59(2):28-37.

Key words: colorectal carcinoma, tumor budding, lymphovascular invasion, perineural invasion

\footnotetext{
${ }^{1}$ University of Niš, Faculty of Medicine, Department of Pathology, Niš, Serbia

${ }^{2}$ University of Niš, Faculty of Medicine, Department of Histology and Embryology, Niš, Serbia

${ }^{3}$ University of Niš, Faculty of Medicine, Department of Internal Medicine and Patient Care, Niš, Serbia

${ }^{4}$ University of Niš, Faculty of Medicine, Department of Oral Surgery, Niš, Serbia

${ }^{5}$ Clinical Center of Niš, Pathology and pathological anatomy Center, Niš, Serbia

${ }^{6}$ Clinical Center of Niš, Cardiovascular Disease Clinic, Niš, Serbia
}

Contact: Tijana V. Denčić

48 Dr Zoran Djindjić Blvd, 18000 Niš, Serbia

E-mail: tijana.dencic29@gmail.com age of 50 , and more than $70 \%$ of carcinomas occur after the age of 60 . Colorectal carcinomas account for $70 \%$ of all malignancies that occur in the gastrointestinal tract (3).They comprise a heterogeneous group of tumors that may develop based on several alternative genetic pathways, each involving different combinations of genetic and epigenetic changes (4). They are a consequence of chromosomal instability, microsatellite instability, and epigenetic mechanisms, and thereby, different responses to applied therapies. The most common histological type is conventional adenocarcinoma more than $90 \%$ originating from epithelial cells of the colorectal mucosa, whereas other histological types are infrequent. Most often they are moderately differentiated more than $70 \%$ and localized in the rectum and sigmoid colon. Large bowel cancers infiltrate the intestinal wall and spread onto regional lymph nodes, and most commonly, metastasizing hematogenously to the liver (5). Patients diagnosed with stage I of the disease have a $97 \%$ probability of five-year survival, whereas in stages II, III and IV the probability decreases to $78 \%, 64 \%$, and $11 \%$, respectively (6). Due to great advancements in the application of neoadjuvant im-munotherapy, chemotherapy, and surgery, patients have a prolonged relapse-free causes of disease and death in the world, especially in developed countries $(1,2)$. They are more frequent in men than in women, developing after the 
period, and permanent remission is achieved in some patients (7-9). In addition to the stage, and histopathology differentiation, there are other prognostic factors that indicate the aggressive behavior of the tumor (10), such characteristics involve tumor budding, lymphovascular invasion and perineural invasion.

Lymphovascular invasion indicates the presence of tumor emboli in lymph and blood vessels. Differentiating venous and lymphatic invasion is important as they have different clinical implications. Presence of lymphatic invasion has been shown to correlate well with lymph node metastasis (11-13), while venous invasion is associated with the potential for visceral metastases occurrence $(14,15)$.

The most widely used definition of PNI is broad, including invasion of tumor cells in, around and through the nerves. Namely, with the presence of tumor cells within any of the 3 layers of the nerve sheath (epineurium, perineurium and endoneurium) or juxtaposition of tumor foci outside of the nerve with involvement of $33 \%$ of the nerve's circumference (16). Some authors report PNI only when tumor cells are observed inside the perineurial layer (17).

Tumor buds signify the presence of individual or smaller groups of cancer cells, less than four cells on the invasive tumor front, and represent an independent indicator of poor prognosis (18-20). It has been observed that in two same-stage cancers, the one with tumor budding will exhibit more aggressive behavior (21). It is thought to be a manifestation of epithelial-mesenchymal transition. This transition is characterized by a serial of cell alterations such as loss of cell adhesion molecules, increased production of extracellular matrix components, cytoskeletal alteration and ability to degrade basement membrane resulting in a phenotype with increased migratory capacity and invasive phenotype (22). Routine reporting is now advocated for extension, outlined by the International Tumor Budding Consensus Conference (ITBCC), with recommendations for the assessment and reporting of tumor budding in colorectal carcinoma (20).

\section{The Aim of the Paper}

The aim of the paper was to determine preference and degree of the association between high grade tumor budding, lymphovascular and perineural invasion with tumor stage in colorectal carcinomas.

\section{Materials and Methods}

The study included histopathology cases of 142 colorectal cancer patients which were undergoing surgical removal of the tumor at the Surgical Clinic of the Clinical Center Niš during the period of one year (2016). Surgically resected samples of large bowel with the tumor were fixed in aqueous $4 \%$ formaldehyde solution ( $10 \%$ formalin solution), and routinely processed to the paraffin blocks. Paraffin sections were stained by hematoxylin and eosin (HE) method. Data used for this research were obtained from the histopathology report archives of the Pathology Center (Clinical Center Niš), included: anatomic localization of the tumor, tumor size, lymph node status, and metastasis stage (TNM), histological type of tumor, histological grade, presence or absence of peritumoral lymphovascular and perineural invasion. Determination of the disease stage as well as histopathology classification of the tumors were performed on the recommendation of AJCC (American Joint Committee on Cancer) (23). The grading system for colorectal cancer is based on the percentage of cancer gland formation. Well differentiated adenocarcinoma exhibits gland formation in more than $95 \%$ of the tumor, moderately differentiated in $50 \%$ to $95 \%$ of the tumor, and poorly differentiated adenocarcinoma exhibits less than $50 \%$ gland formation. Poorly differentiated adenocarcinoma accounts for $5 \%$ to $10 \%$ of all cases and are associated with a greater incidence of adverse outcome. Tumor buddings defined as single tumor cells or cluster of less than four cells at the invasive front of tumor. The quantification of tumor budding at the invasive front of tumor has been assessed on HE stained slides at magnification x100, thereby identifying fields with the highest density of tumor budding which are then analyzed at magnification $x 200$. The specimen with the highest number of tumor budding is considered a hotspot (in a field measuring $0.785 \mathrm{~mm}^{2}$ ). A two-tier system was used: low grade (0-9 tumor buds); and high grade $(\geq 10)$.

\section{Statistical Analysis}

Interrelationships between tumor location and clinicopathological characteristics were analyzed using Chi square $\left(\chi^{2}\right)$ test. The univariate Cox proportional hazards regression using to calculate hazard ratios and 95\% confidence intervals. Variables found to be statistically significant $(p<0.05$ ). Analyses were performed using SPSS software version 24.

\section{Results}

The study consisted of 142 patients aged 67.4 \pm 10.0 years, with age ranging from 22 to 88 years. Male subjects were predominant $(62.7 \%)$, and their number was statistically significantly higher than the number of female subjects ( $p<0.05$ ) (Table 1$)$.

Colorectal cancers were most commonly localized in the rectum (35.2\%), which is statistically a more frequent localization compared to the sigmoid colon and other less represented localizations ( $p<$ 0.001 ). The most prevalent histological type conventional adenocarcinoma was present in 116 patients $(81.7 \%)$ and was statistically far more present than other histological types ( $p<0.001)$. The histological grade $\mathrm{G} 2$ was reported in 111 patients $(78.2 \%)$ and was statistically more common than the histological grade G3 ( $p<0.01)$. The depth of invasion T3 was present in 96 patients (67.6\%) and was statistically more frequent than other depth of 
invasion categories individually $(p<0.001)$. Metastases to regional lymph nodes were present in just over half of patients - $72(50.7 \%)$, and compared to the total number of patients they averaged $2.6 \pm$ 4.7, with very high standard deviation given that the number of metastases to regional lymph nodes ranged from 0 to 27 . Stage III was the most common stage and was reported in 72 patients (50.7\%), which was statistically more frequent compared to other stages individually. Clinical and pathological features are shown in Table 2.

Table 1. Demographic characteristics of subjects

\begin{tabular}{|cccc||}
\hline Gender & $\mathrm{n}$ & $\%$ & Range \\
\hline Female & 53 & 37.3 & \\
Male & 89 & $62.7^{*}$ & \\
\hline Age & 67.4 & \pm 10.0 & $(22-88)$ \\
\hline $\mathrm{p}<0.05$ & & &
\end{tabular}

Table 2. Clinicopathological characteristics of the tumours

\begin{tabular}{|c|c|c|c|}
\hline Localization & 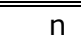 & $\%$ & \\
\hline Caecum & 22 & 15.5 & \\
\hline Ascending colon & 15 & 10.6 & \\
\hline Transverse colon & 8 & 5.6 & \\
\hline Descending colon & 6 & 4.2 & \\
\hline Sigmoid colon & 41 & 28.9 & \\
\hline Rectum & 50 & 35.2 & $* * *$ \\
\hline \multicolumn{4}{|l|}{ Histological type } \\
\hline Adenocarcinoma Conventional & 116 & 81.7 & $* * *$ \\
\hline Mucinous Adenocarcinoma & 21 & 14.8 & \\
\hline Mixed Adenoneuroendocrine carcinoma & 2 & 1.4 & \\
\hline Signet ring cell carcinoma & 3 & 2.1 & \\
\hline \multicolumn{4}{|l|}{ Histological grade } \\
\hline $\mathrm{G} 2$ & 111 & 78.2 & $* *$ \\
\hline G3 & 31 & 21.8 & \\
\hline \multicolumn{4}{|l|}{ Depth of invasion } \\
\hline $\mathrm{T} 1$ & 1 & 0.7 & \\
\hline $\mathrm{T} 2$ & 24 & 16.9 & \\
\hline T3 & 96 & 67.6 & *** \\
\hline $\mathrm{T} 4 \mathrm{a}$ & 14 & 9.9 & \\
\hline $\mathrm{T} 4 \mathrm{~b}$ & 7 & 4.9 & \\
\hline Metastases to regional lymph nodes & 72 & 50.7 & \\
\hline Average number of metastases to regional lymph nodes ${ }^{a}$ & 2.6 & \pm 4.7 & \\
\hline \multicolumn{4}{|l|}{ TNM stage } \\
\hline I & 18 & 12.7 & \\
\hline II & 45 & 31.7 & \\
\hline III & 72 & 50.7 & $* * *$ \\
\hline IV & 7 & 4.9 & \\
\hline
\end{tabular}

Lymphovascular invasion is the presence of single tumor cells or small cluster in a space lined by endothelial cells and/or containing erythrocytes surrounding the tumor cells. Vascular and lymphatic invasion in colorectal cancer (Figure 1 and 2).

Perineural invasion was detected in all neural components of nerve fascicles, usually in form of single cancer glands, or less often as groups or single cancer cells (Figure 3 ).

Tumor buds were detected as the presence of single cells or small clusters of cancer cells at the invasive front of a tumor (Figure 4). 


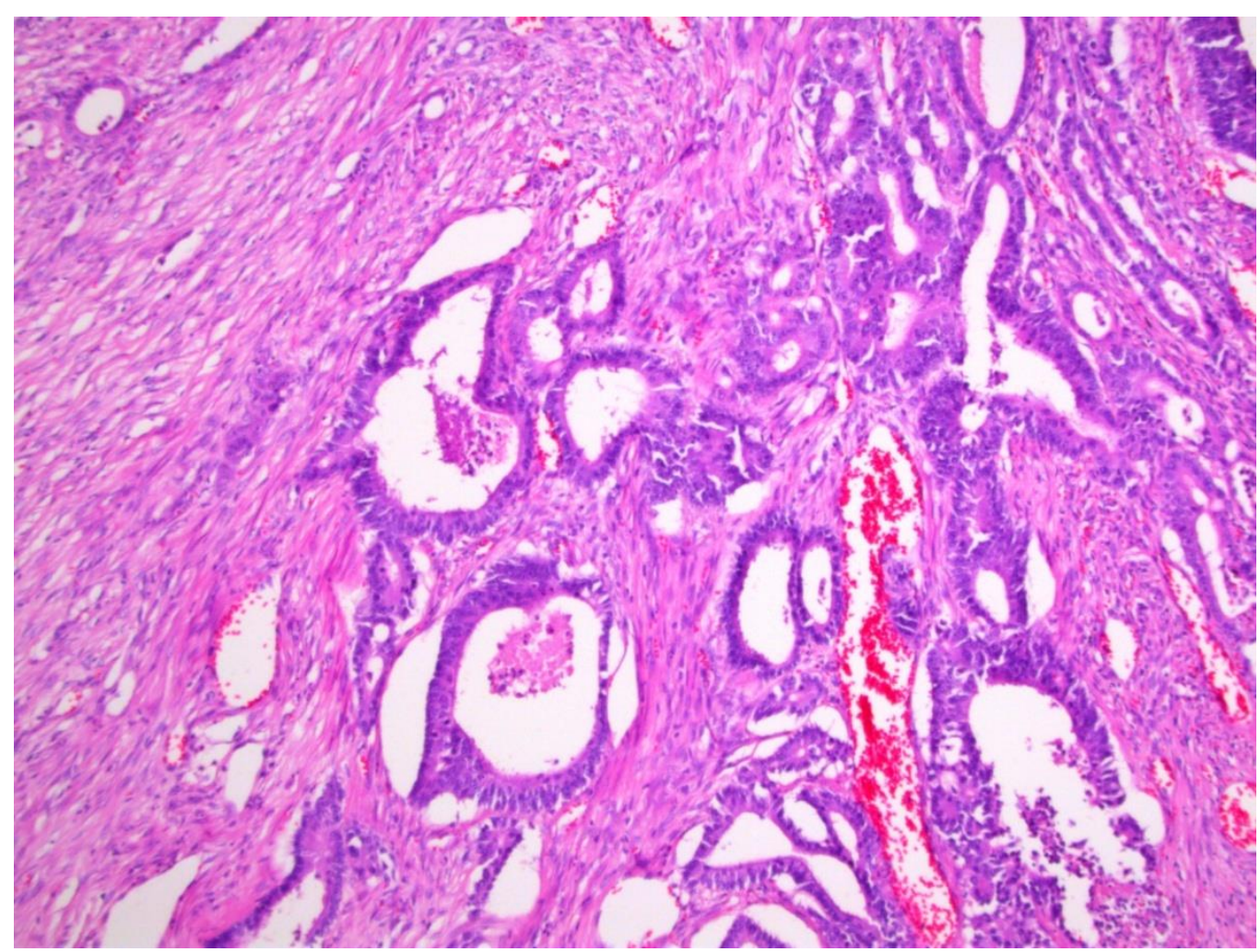

Figure 1. Intravascular invasion. Presence of cancer cell cluster in lumen of small vein. (HE, x200)

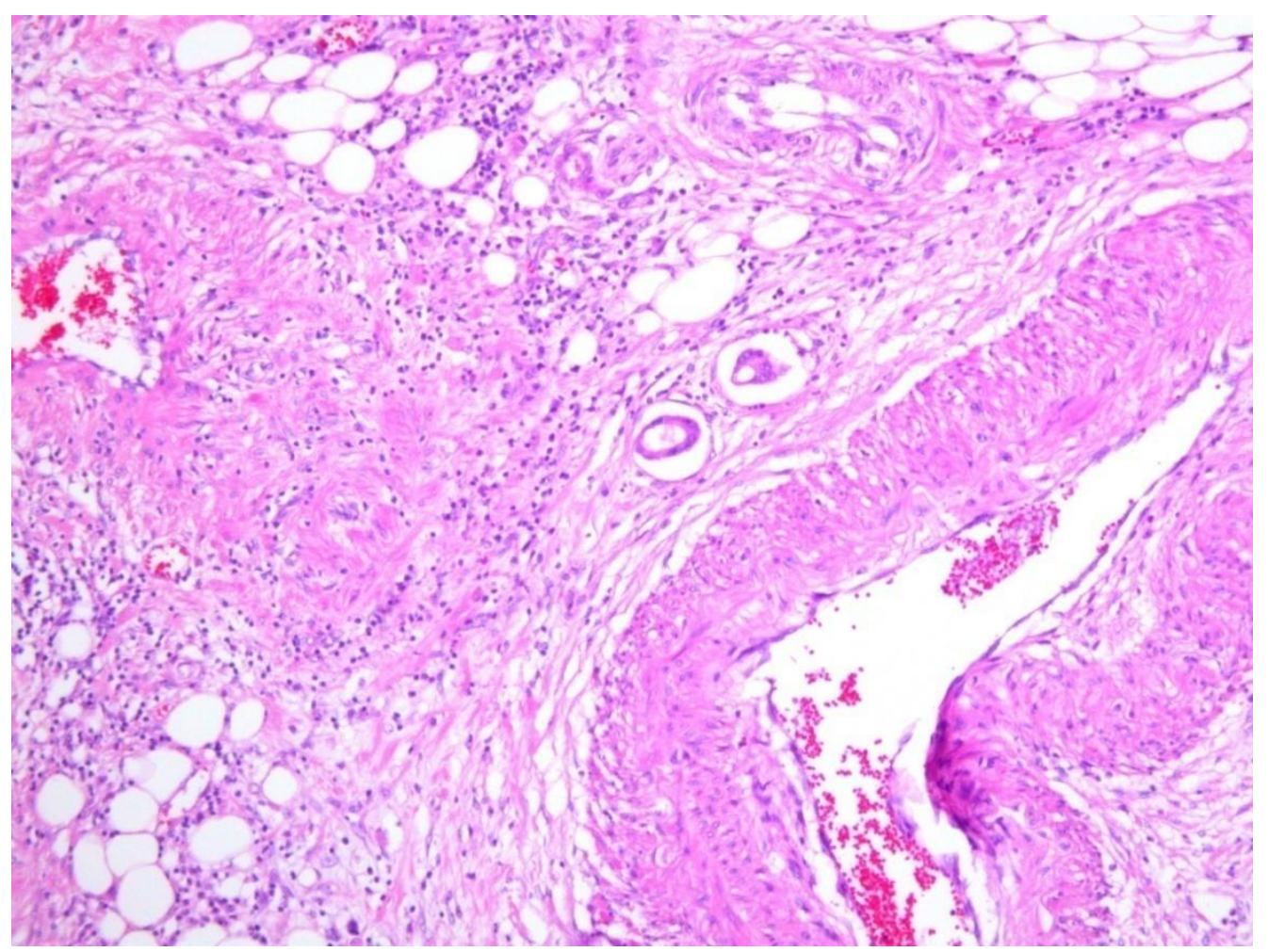

Figure 2. Cancer invasion of lymph vessels. Lumina of small lymphatic vessels occupied with cancer cell clusters. (HE, x200) 


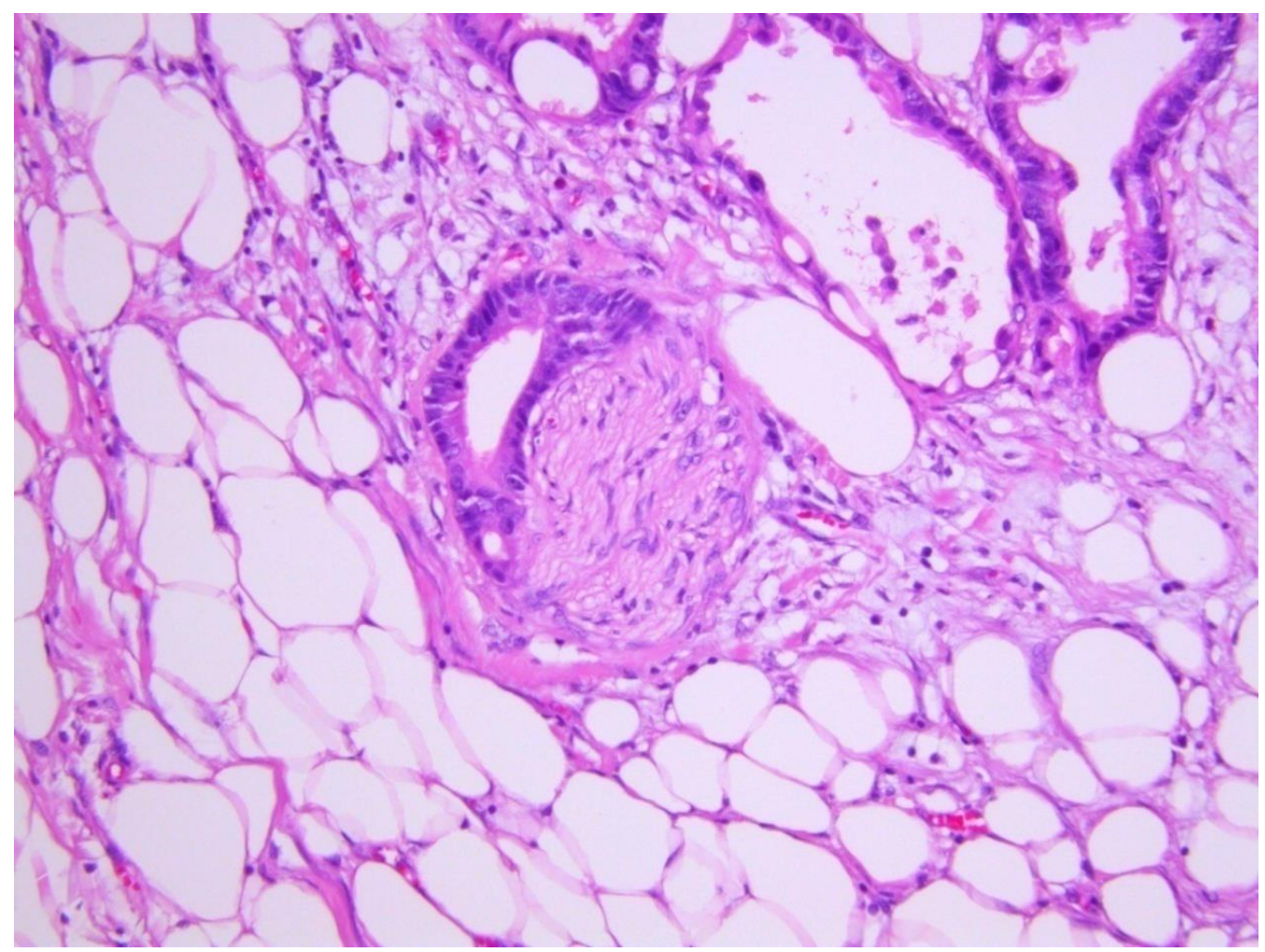

Figure 3. The most usually finding of PN was the juxtaposition of cancer glands to perineurium of nerve fascicles. $(\mathrm{HE}, \mathrm{x} 200)$

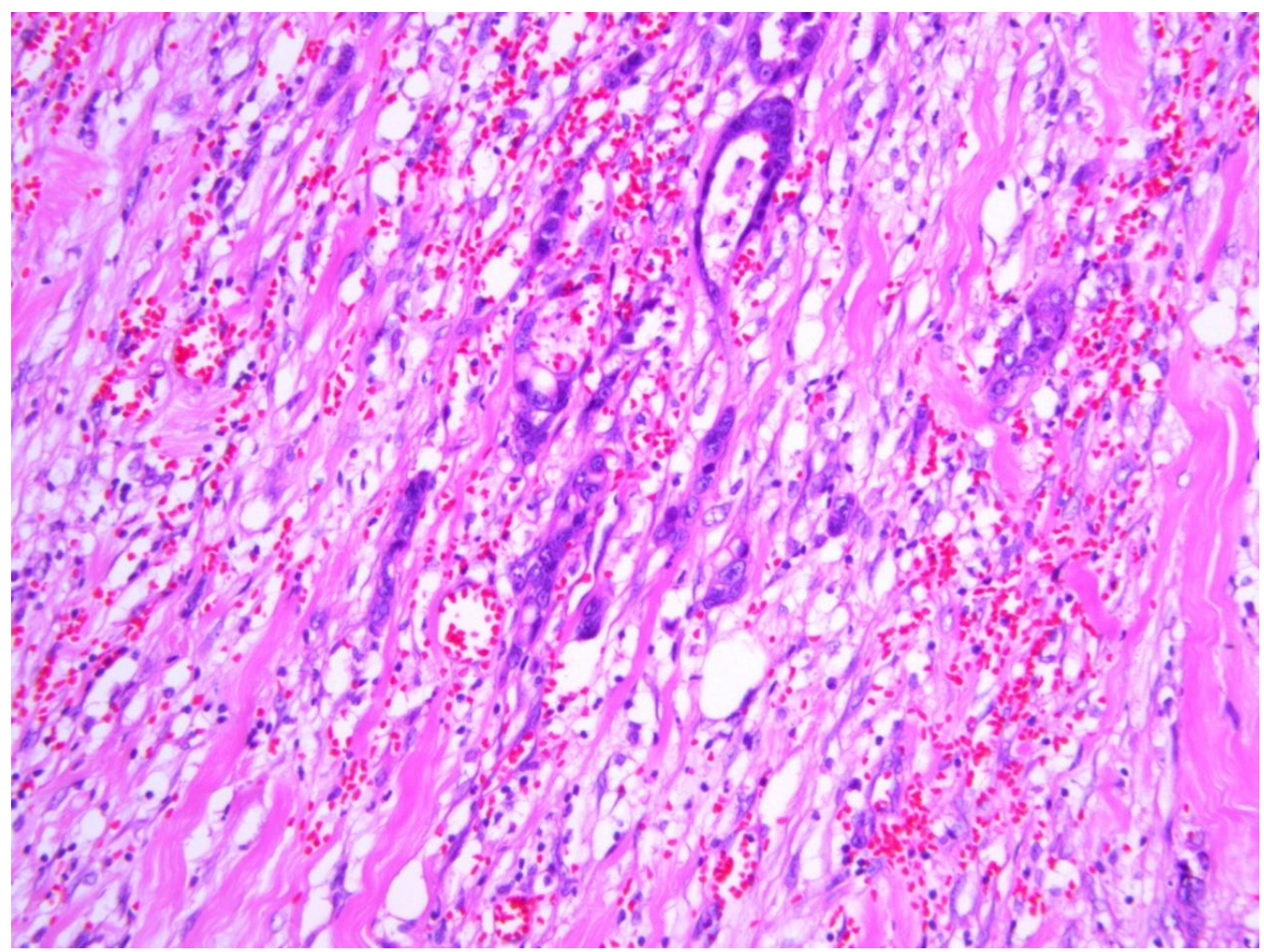

Figure 4. High grade tumor budding. Cancer cell strands, small clusters or single cells, extending from tumor periphery toward inflammatory reactive surrounding. (HE, x200). 
Perineural invasion was found in 29 patients (20.4\%). It was statistically considerably less common compared to lymphovascular invasion, reported in 57 patients $(40.2 \%)$, or high grade tumor budding, reported in 63 patients $(p<0.001)$. The presence of lymphovascular invasion, perineural invasion and high grade tumour budding are shown in Table 3.

The univariate logistic regression analysis found that the odds ratio for the presence and absence of lymphovascular invasion showed a 13.8fold increase in stage III or higher (5.6 to 34.2; $p<$ 0.001). The relationship between lymphovascular invasion and TNM advanced stage are shown in Table 4.
The univariate logistic regression analysis found that the odds ratio for the presence and absence of perineural invasion showed a 6.8-fold increase in stage III or higher (2.2 to 20.9; $p<$ $0.001)$. The relationship between perineural invasion and TNM advanced stage are shown in Table 5.

The univariate logistic regression analysis found that the odds ratio for low and high-grade tumor budding showed a 2.3-fold increase in stage III or higher ( 1.1 to $4.5 ; p<0.05)$. The relationship between tumor budding and TNM advanced stage are shown in Table 6.

Table 3. The presence of lymphovascular invasion, perineural invasion, and high grade tumor budding

\begin{tabular}{|lllll||}
\hline \hline Lymphovascular invasion & 57 & $40.2 \%$ & ${ }^{* * *}$ \\
Perineural invasion & 29 & $20.4 \%$ & \\
High grade tumor budding & 63 & $44.4 \%$ & \\
\hline$* * * \mathrm{p}<0.001\left(\chi^{2}\right.$ test $)$ & & &
\end{tabular}

Table 4. The assessment of the stage on the presence of lymphovascular invasion - results of the univariate logistic regression analysis

\begin{tabular}{|lcccc|}
\hline \multirow{2}{*}{ Factor } & \multirow{2}{*}{ OR } & \multicolumn{2}{c|}{ Limits $95 \%$} & $\mathrm{p}$ \\
\cline { 3 - 4 } & & Lower & Upper & \\
\hline Stage $\geq$ III & 13.8 & 5.6 & 34.2 & $<0.001$ \\
\hline
\end{tabular}

Table 5. The assessment of the stage on the presence of perineural invasion - results of the univariate logistic regression analysis

\begin{tabular}{||ccccc||}
\hline \multirow{2}{*}{ Factor } & OR & \multicolumn{2}{c|}{ Limits $95 \%$} & $\mathrm{p}$ \\
\cline { 3 - 4 } & & Lower & Upper & \\
\hline Stage $\geq$ III & 6.8 & 2.2 & 20.9 & 0.0008 \\
\hline
\end{tabular}

Table 6. The assessment of the stage on the presence of tumor budding - results of the univariate logistic regression analysis

\begin{tabular}{||lcccc||}
\hline \multirow{2}{*}{ Factor } & \multirow{2}{*}{ OR } & \multicolumn{2}{c||}{ Limits 95\% } & \multirow{2}{*}{$\mathrm{p}$} \\
\cline { 3 - 4 } & & Lower & Upper & \\
\hline Stage $\geq$ III & 2.3 & 1.1 & 4.5 & 0.019 \\
\hline
\end{tabular}




\section{Discussion}

Colorectal carcinoma is one of the leading health problems in the world $(1,2)$. It occurs in elderly people after the age of 60 and is more common in men than in women. In our study, the mean age of patients was $67.4 \pm 10.0$ years, with age ranging from 22 to 88 years. The overall specimen is dominated by male patients $(62.7 \%)$, who statistically significantly outnumbered female patients ( $p<$ 0.05). The largest number of these cancers was developed in the wall of the rectum, which is consistent with literature data (3).

Conventional adenocarcinomas were diagnosed in $81.7 \%$ of patients, whereas mucinous adenocarcinoma was reported in about $14.8 \%$ of patients, which is in accordance with the literature data (24, 25). Mucinous adenocarcinoma is a distinct subtype and is characterized by abundant mucinous components that comprise at least $50 \%$ of the tumor volume (26). In our study, $78.2 \%$ of colorectal carcinomas were of histology grade G2, and $21.8 \%$ of histology grade $\mathrm{G} 3$. The largest number of colorectal carcinomas was in stage III and II, 50.7\% and $31.7 \%$, respectively, whereas $4.9 \%$ of carcinomas were in stage IV. Stage I carcinomas amounted to only $12.7 \%$, indicating that early diagnosis and screening for colorectal carcinoma were inadequate.

Tumor budding has been found to be an independent adverse prognostic factor in CRC and is a strong predictor of lymph node involvement, venous and lymphatic invasion, local recurrence, metastases and poor disease free survival (27), and in addition to lymphovascular and perineural invasion, it is a factor indicating more aggressive tumor behavior $(21,28,29,30)$. It has been observed that in two same-stage carcinomas, the one with tumor budding will exhibit more aggressive behavior (30). After the examination of our research material, high grade tumor budding was found in 63 patients (44.4\%). Furthermore, a statistically significant correlation was discovered between high grade tumor budding and higher stages of colorectal carcinoma (31). However, recognition of tumor budding on H\&E may occasionally present some challenges because of the presence of reactive stromal cells or histiocytes surrounding the invasive front of tumor and cytokeratin immunostaining can be performed to confirm the impression of tumor buds (32).

Lymphovascular invasion is defined as the presence of single cancer cells or cancer cell clusters within an endothelial lined channel surrounding smooth muscle or elastic lamina (33). The reporting of vascular invasion is highly variable and underreported, due to the interobserver variability (34), with the incidence of venous invasion reported between $11 \%$ and $89.5 \%$ (15). Lymphovascular invasion is one of the significant factors indicating the biological aggressiveness of tumors (11-13, 33, 35, $36)$. In our study, lymphovascular invasion was present in 57 patients (40.1\%) and showed statistical significance in relation to the advanced stage of the disease.

Perineural invasion (PNI) is a continuous and multistep process of interaction developing between nerve structures and cancer cells $(37,38)$. Nerve cells and tumor cells can interact directly or through the opening and closing of the signal transduction pathways and/or the recognition and response of the ligands and receptors. Schwann cells mediate perineural invasion. Dedifferentiated Schwann cells come into direct contact with cancer cells. This direct contact results in the extension of protrusions from the cancer cells. Schwann cells intercalate between cancer cells, thereby promoting cancer dispersal from the tumor and migration toward the neural fascicles. Perineural invasion is an indicator of poor prognosis $(39,40)$. A recent large meta-analysis has shown that perineural invasion represents an independent prognostic factor and that stage II tumor patients with perineural invasion have poorer survival than stage III tumor patients without perineural invasion (24). PNI is associated with other pathological markers of poor prognosis such as lymphovascular invasion, poor differentiation and tumor budding (41). Our study confirmed perineural invasion in 29 patients (20.4\%) and a statistically significant association with higher stages of the disease $(16,42)$.

Authors suggest that the TNM staging most accurately determines the prognosis of colorectal carcinoma (43), we find that additional diagnostic parameters, such as tumor budding, lymphovascular and perineural invasion are in strong correlation with advanced tumor stages. Tumor budding should be included in routine diagnostics, for a more accurate therapy and better patient follow-up.

\section{Conclusion}

In evaluated histopathology cases of colorectal cancers, lymphovascular invasion and tumor budding were statistically significantly often findings, than perineural invasion. The univariate logistic regression analysis revealed a statistically significant correlation between tumor budding, lymphovascular and perineural invasion and higher tumor stages in colorectal carcinoma. The ITBCC evaluation method should be used to assess tumor budding and may form the basis of a new staging system in patient with colorectal cancer.

\section{Acknowledgments}

This work has been supported by the Internal Scientific Research Project of the Faculty of Medicine, University of Niš (INT-MFN, No.38/20).

\section{Conflict of Interests}

The authors declare that they have no conflict of interests. 


\section{References}

1. Ferlay J, Colombet M, Soerjomataram I, Mathers C, Parkin D, Piñeros $M$, et al. Estimating the global cancer incidence and mortality in 2018: GLOBOCAN sources and methods. Int J Cancer 2019;144(8):1941-1953. [CrossRef] [PubMed]

2. Bray F, Ferlay J, Soerjomataram I, Siegel R, Torre L, Jemal A. Global cancer statistics 2018: GLOBOCAN estimates of incidence and mortality worldwide for 36 cancers in 185 countries. CA Cancer J Clin 2018; 68 (6):394-424. [CrossRef] [PubMed]

3. Ponz de Leon M, Di Gregorio C. Pathology of colorectal cancer. Dig Liver Dis 2001;33(4):372-88. [CrossRef] [PubMed]

4. Al-Sohaily S, Biankin A, Leong R, Kohonen-Corish M, Warusavitarne J. Molecular pathways in colorectal cancer. J Gastroenterol Hepatol 2012;27(9):1423-31. [CrossRef] [PubMed]

5. Loughrey M, Quirke P, Shepherd N. Standards and datasets for reporting cancers. Dataset for histopathological reporting of colorectal cancer. Sep 2018. https://www.rcpath.org/uploads/assets/uploaded/0d5 e22ce-be66-474c-ba3097adae84121d. Assessed 23 Feb 20. [CrossRef]

6. Quaresma M, Coleman M, Rachet B. 40-year trends in an index of survival for all cancers combined and survival adjusted for age and sex for each cancer in England and Wales, 1971-2011: a population-based study. Lancet 2015;385(9974):1206-18.

[CrossRef] [PubMed]

7. Walsh S, Carey F. Malignant epithelial neoplasms of the large bowel. In: Shepherd NA, Warren BF, Williams GT, Greenson JK, Lauwers GY NM, editor. Morson and Dawson's gastrointestinal pathology. $5^{\text {th }}$ ed. Oxford: Wiley-Blackwell; 2013. p. 685-732. [CrossRef] [PubMed]

8. Thompson S, Bakhoum S, Compton D. Mechanisms of chromosomal instability. Curr Biol 2010;20(6):R28595. [CrossRef] [PubMed]

9. Pino $M$, Chung $D$. The chromosomal instability pathway in colon cancer. Gastroenterology 2010;138(6): 2059-72. [CrossRef] [PubMed]

10. Park J, McMillan D, Powell A, Richards C, Horgan P, Edwards J, et al. Evaluation of a tumor microenvironment-based prognostic score in primary operable colorectal cancer. Clin Cancer Res 2015;21(4):882-8. [CrossRef] [PubMed]

11. Glasgow S, Bleier J, Burgart L, Finne C, Lowry A. Meta-analysis of histopathological features of primary colorectal cancers that predict lymph node metastases. J Gastrointest Surg 2012;16(5):1019-28. [CrossRef] [PubMed]

12. Huh J, Kim H, Kim Y. Lymphovascular or perineural invasion may predict lymph node metastasis in patients with T1 and T2 colorectal cancer. J Gastrointest Surg 2010;14(7):1074-80. [CrossRef] [PubMed]

13. Huh J, Lee W, Shin J, Park Y, Cho Y, Kim H, et al. A novel histologic grading system based on lymphovascular invasion, perineural invasion, and tumor budding in colorectal cancer. J Cancer Res Clin Oncol 2019;145(2):471-477. [CrossRef] [PubMed]

14. Sejben I, Bori R, G. C. Venous invasion demonstrated by orcein staining of colorectal carcinoma specimens is associated with the development of distant metastasis. J Clin Pathol 2010;63(7):575-8.

[CrossRef] [PubMed]
15. Messenger D, Driman D, McLeod R, Riddell R, Kirsch R. Current practice patterns among pathologists in the assessment of venous invasion in colorectal cancer. ] Clin Pathol 2011;64(11):983-9. [CrossRef] [PubMed]

16. Liebig C, Ayala G, Wilks J, Berger D, Albo D. Perineural invasion in cancer: A review of the literature. Cancer 2009;115(15):3379-91. [CrossRef] [PubMed]

17. Ceyhan G, Liebl F, Maak M, Schuster T, Becker K, Langer $R$, et al. The severity of neural invasion is a crucial prognostic factor in rectal cancer independent of neoadjuvant radiochemotherapy. Ann Surg 2010; 252(5): 797-804. [CrossRef] [PubMed]

18. Ueno $H$, Murphy J, Jass JR, Mochizuki H, Talbot IC. Tumour "budding" as an index to estimate the potential of aggressiveness in rectal cancer. Histopathology 2002;40(2):127-32. [CrossRef] [PubMed]

19. Morodomi $T$, Isomoto $H$, Shirouzu $K$, Kakegawa $K$, Irie $\mathrm{K}$, Morimatsu M. An index for estimating the probability of lymph node metastasis in rectal cancers. Lymph node metastasis and the histopathology of actively invasive regions of cancer. Cancer 1989; 63(3):539-43. [CrossRef] [PubMed]

20. Lugli A, Kirsch R, Ajioka Y, Bosman F, Cathomas G, Dawson $\mathrm{H}$, et al. Recommendations for reporting tumor budding in colorectal cancer based on the International Tumor Budding Consensus Conference (ITBCC) 2016. Mod Pathol 2017;30(9):1299-311. [CrossRef] [PubMed]

21. Ohtsuki K, Koyama F, Tamura T, Enomoto Y, Fujii $H$, Mukogawa $T$, et al. Prognostic value of immunohistochemical analysis of tumor budding in colorectal carcinoma. Anticancer Res 2008;28(3B):1831-6. [CrossRef] [PubMed]

22. Yamada N, Sugai T, Eizuka M, Tsuchida K, Sugimoto $R$, Mue $Y$, et al. Tumor budding at the invasive front of colorectal cancer may not be associated with the epithelial-mesenchymal transition. Hum Pathol 2017; 60:151-9. [CrossRef] [PubMed]

23. Edge SB, Byrd DR, Compton CC, Fritz AG, Greene FL TA, editor. AJCC cancer staging manual. $7^{\text {th }}$ ed. New York: NY: Springer; 2010.173-206 p. [CrossRef]

24. Hugen N, van Beek J, de Wilt J, Nagtegaal I. Insight into mucinous colorectal carcinoma: clues from etiology. Ann Surg Oncol 2014;21(9):2963-70. [CrossRef] [PubMed]

25. Leopoldo S, Lorena B, Cinzia A, Gabriella D, Angela Luciana B, Renato C, et al. Two subtypes of mucinous adenocarcinoma of the colorectum: clinicopathological and genetic features. Ann Surg Oncol 2008;15(5): 1429-39. [CrossRef] [PubMed]

26. Glasgow S, Yu J, Carvalho L, Shannon W, Fleshman J, McLeod $\mathrm{H}$. Unfavourable expression of pharmacologic markers in mucinous colorectal cancer. $\mathrm{Br} \mathrm{J}$ Cancer. 2005;92(2):259-64. [CrossRef] [PubMed]

27. Wang L, Kevans D, Mulcahy H, O'Sullivan J, Fennelly D, Hyland J, et al. Tumor budding is a strong and reproducible prognostic marker in T3NO colorectal cancer. Am J Surg Pathol 2009;33(1):134-41. [CrossRef] [PubMed]

28. Park KJ, Choi HJ, Roh MS, Kwon HC, Kim C. Intensity of tumor budding and its prognostic implications in invasive colon carcinoma. Dis Colon Rectum 2005: 48(8):1597-602. [CrossRef] [PubMed]

29. Ueno $H$, Mochizuki $H$, Shinto $E$, Hashiguchi $Y$, Hase $K$, Talbot IC. Histologic indices in biopsy specimens for estimating the probability of extended local spread in 
patients with rectal carcinoma. Cancer 2002;94(11): 2882-91. [CrossRef] [PubMed]

30. Okuyama T, Nakamura T, Yamaguchi M. Budding is useful to select high-risk patients in stage II welldifferentiated or moderately differentiated colon adenocarcinoma. Dis Colon Rectum. 2003;46(10): 1400-6. [CrossRef] [PubMed]

31. Betge J, Kornprat $P$, Pollheimer $M$, Lindtner $R$, Schlemmer A, Rehak $P$, et al. Tumor budding is an independent predictor of outcome in AJCC/UICC stage II colorectal cancer. Ann Surg Oncol 2012;19(12): 3706-12. [CrossRef] [PubMed]

32. Cho S, Kakar S. Tumor Budding in Colorectal Carcinoma: Translating a Morphologic Score Into Clinically Meaningful Results. Arch Pathol Lab Med 2018;142(8):v952-7. [CrossRef] [PubMed]

33. Roxburgh C, McMillan D, Anderson J, McKee R, Horgan $P$, Foulis A. Elastica staining for venous invasion results in superior prediction of cancer-specific survival in colorectal cancer. Ann Surg 2010;252(6):989-97. [CrossRef] [PubMed]

34. Harris $E$, Lewin D, Wang $H$, Lauwers $G$, Srivastava $A$, Shyr $Y$, et al. Lymphovascular invasion in colorectal cancer: an interobserver variability study. Am J Surg Pathol 2008;32(12):1816-21. [CrossRef] [PubMed]

35. Zlobec I, Lugli A. Prognostic and predictive factors in colorectal cancer. J Clin Pathol 2008;61(5):561-9. [CrossRef] [PubMed]

36. Yuan H, Dong Q, Zheng B, Hu X, Xu J, Tu S. Lymphovascular invasion is a high risk factor for stage I/II colorectal cancer: a systematic review and metaanalysis. Oncotarget 2017;8(28):46565-79.
[CrossRef] [PubMed]

37. Azam S, Pecot C. Schwann cells drive perineural invasion. J Clin Invest 2016;126(4):1242-4. [CrossRef] [PubMed]

38. Chen S, Zhang B, Zhou B, Zhu C, Sun L, Feng Y. Perineural invasion of cancer: a complex crosstalk between cells and molecules in the perineural niche. Am J Cancer Res 2019;9(1):1-21.

[CrossRef] [PubMed]

39. Liebig C, Ayala G, Wilks J, Verstovsek G, Liu H, Agarwal $N$, et al. Perineural invasion is an independent predictor of outcome in colorectal cancer. J Clin Oncol 2009;27(31):5131-7. [CrossRef] [PubMed]

40. Yang $Y$, Huang $X$, Sun J, Gao $P$, Song $Y$, Chen $X$, et al. Prognostic value of perineural invasion in colorectal cancer: a meta-analysis. J Gastrointest Surg 2015; 19(6):1113-22. [CrossRef] [PubMed]

41. Poeschl $E$, Pollheimer $M$, Kornprat $P$, Lindtner $R$, Schlemmer $A$, Rehak $P$, et al. Perineural invasion: correlation with aggressive phenotype and independent prognostic variable in both colon and rectum cancer. J Clin Oncol 2010;28(21):358-60.

[CrossRef] [PubMed]

42. Knijn N, Mogk S, Teerenstra S, Simmer F, Nagtegaal I. Perineural Invasion is a Strong Prognostic Factor in Colorectal Cancer: A Systematic Review. Am J Surg Pathol 2016;40(1):103-12. [CrossRef] [PubMed]

43. Puppa G, Sonzogni A, Colombari R, Pelosi G. TNM staging system of colorectal carcinoma: a critical appraisal of challenging issues. Arch Pathol Lab Med 2010;134(6):837-52. [CrossRef] [PubMed] 


\title{
PREDIKTIVNI ZNAČAJ TUMORSKOG PUPLJENJA, LIMFOVASKULARNE I PERINEURALNE INVAZIJE KOD KOLOREKTALNOG KARCINOMA
}

\author{
Tijana Denčić1,5, Maja Jovičić-Milentijević1,5, Aleksandar Petrović2, Goran Radenković2, \\ Marko Jović2 ${ }^{2}$ Sonja Šalinger-Martinović3,6, Simona Stojanović ${ }^{4}$
}

\begin{abstract}
Kontakt: Tijana V. Denčić
Bulevar dr Zorana Đinđića 48, 18000 Niš, Srbija

E-mail: tijana.dencic29@gmail.com
\end{abstract}

${ }^{1}$ Univerzitet u Nišu, Medicinski fakultet, Katedra za patologiju, Niš, Srbija

${ }^{2}$ Univerzitet u Nišu, Medicinski fakultet, Katedra za histologiju i embriologiju, Niš, Srbija

${ }^{3}$ Univerzitet u Nišu, Medicinski fakultet, Katedra za internu medicinu i zdravstvenu negu, Niš, Srbija

${ }^{4}$ Univerzitet u Nišu, Medicinski fakultet, Katedra za oralnu hirurgiju, Niš, Srbija

${ }^{5}$ Klinilki centar Niš, Centar za patologiju i patološku anatomiju, Niš, Srbija

${ }^{6}$ Klinički centar Niš, Klinika za kardiovaskularne bolesti, Niš, Srbija

Kolorektalni karcinomi predstavljaju jedan od čestih uzroka oboljevanja i smrtnog ishoda u svetu. Na globalnom nivou, nalazi se na šestom mestu kod muškaraca i na četvrtom mestu kod žena. Kolorektalni karcinomi predstavljaju heterogenu grupu tumora, koji mogu da nastanu na osnovu nekoliko alternativnih genetskih puteva, od kojih svaki uključuje različite kombinacije genetskih i epigenetskih promena. Mnogi autori navode to da TNM stadijum najpreciznije određuje prognozu kolorektalnog karcinoma, međutim, potrebni su i drugi parametri. Osim TNM stadijuma, postoje i drugi prognostički faktori koji ukazuju na agresivno ponašanje tumora. Takvi parametri su limfovaskularna invazija, perineuralna invazija i tumorsko pupljenje. Obrađena su 142 bolesnika sa kolorektalnim karcinomom, koja su operisana na Hirurškoj klinici u Nišu. Cilj rada je da se utvrdi da li postoji povezanost tumorskog pupljenja, limfovaskularne invazije i perineuralne invazije, u odnosu na stadijum tumorske bolesti kod kolorektalnih karcinoma. Stadijum tumorske bolesti određen je na osnovu TNM klasifikacije preporučene od strane WHO i AJCC. U ovom radu, univarijantnom logističkom regresionom analizom, nađena je statistički značajna povezanost tumorskog pupljenja, limfovaskularne i perineuralne invazije sa uznapredovalim stadijumom tumorske bolesti.

Acta Medica Medianae 2020;59(2):28-37.

Ključne reči: kolorektalni karcinom, tumorsko pupljenje, limfovaskularna invazija, perineuralna invazija 